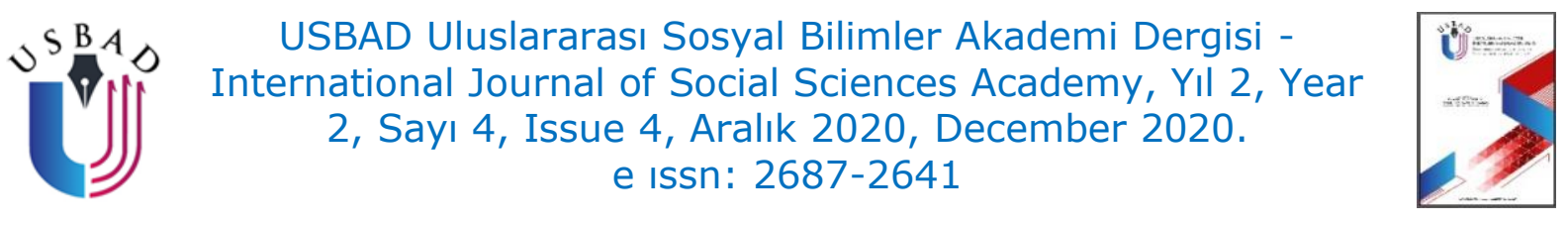

\title{
SOSYAL BİLGİLER ÖĞRETMEN ADAYLARININ 21. YÜZYIL ÖĞRETEN VE ÖĞRENEN BECERİLERİNİN İNCELENMESİ
}

\section{INVESTIGATION OF SOCIAL STUDIES TEACHER CANDIDATES' 21ST CENTURY TEACHING AND LEARNER SKILLS}

\author{
Hasan AYDEMİR \\ Doç. Dr. İnönü \\ Üniversitesi Eğitim \\ Fakültesi, Temel Eğitim \\ Bölümü, \\ Malatya/Türkiye. \\ Inonu University Faculty \\ of Education, \\ Department of Primary \\ Education. \\ Malatya/Turkey. \\ hasan.aydemir@inonu.edu.tr \\ ORCID ID: 0000-0002-
}

3073-9194

\author{
Yalçın KARALI \\ Dr., Eğitim Bilimleri \\ Anabilim Dalı, Sınıf \\ Eğitimi Bilim Dalı, İnönü \\ Üniversitesi Eğitim \\ Fakültesi, \\ Malatya/Türkiye. \\ Phd., Department of \\ Educational Sciences, \\ Classroom Education, \\ Inönü University Faculty \\ of Education, \\ Malatya/Turkey. \\ yalcin.karali@inonu.edu.tr
}

ORCID ID: 0000-0002-

8977-5034

\section{Gökhan COŞANAY}

Milli Eğitim Bakanlığı, Malatya/Türkiye.

Ministry of Education,

Malatya/Turkey.

gokhancosanay44@hotmail.com

ORCID ID: 0000-0003-

1767-2711

Makale bilgisi | Article Information

DOI: $10.47994 /$ usbad. 824081

Makale Türü / Article Type: İnceleme Makalesi / Research Article

Geliş Tarihi / Date Received: 10.11.2020

Kabul Tarihi / Date Accepted: 23.12.2020

Yayın Tarihi / Date Published: 20.12.2020

Yayın Sezonu / Pub Date Season: Aralık / December

Bu Makaleye Atıf İçin / To Cite This Article: Aydemir, H., Karalı, Y., Coşanay, G. (2020). Sosyal Bilgiler Öğretmen Adaylarının 21. Yüzyıl Öğreten ve Öğrenen Becerilerinin İncelenmesi. USBAD Uluslararası Sosyal Bilimler Akademi Dergisi 2(4), 1199-1214.

İntihal: Bu makale intihal.net yazılımınca taranmıştır. İntihal tespit edilmemiştir.

Plagiarism: This article has been scanned by intihal.net. No plagiarism detected.

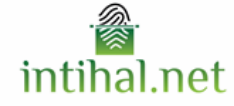

İletişim: Web: https://dergipark.org.tr/tr/pub/usbad mail: usbaddergi@gmail.com 
Hasan Aydemir - Yalçın Karalı - Gökhan Coşanay

Öz: Bilginin hızla çoğaldığı ve değiştiği 21. yüzyılda toplumsal düzen ve bireysel intiyaçlar da hızla değişim göstermektedir. Bununla birlikte yeni iş alanları ve meslekler ortaya çıkmaktadır. Ülkelerin bu yeni oluşuma ayak uydurabilmeleri sahip oldukları insan potansiyelini yeni yüzyılın mesleki ihtiyaçlarını karşılayabilecek bireyler olarak yetiştirmelerine bağlıdır. Bu da yeni yüzyıl intiyaçlarına cevap vereceği öngörülen 21 . yüzyıl becerileri eğitim programlarının uygulanmasıyla mümkün olacaktır. Burada en önemli görev bu eğitim programlarını uygulayacak olan öğretmenlere düşmektedir. Bu nedenle 21. yüzyıl becerilerinin öğrencilere kazandırılabilmesi için öncelikle bu becerilere sahip öğretmenlerin yetiştirilmesi gerekir. Bu doğrultuda araştırmanın amacı 21. yüzyılın hem öğreneni hem de öğreteni olacak olan öğretmen adaylarının bu becerilere ne düzeyde sahip olduklarını incelemek ve bu becerilere sahip olma düzeylerinin cinsiyet ve sınıf değişkenlerine göre farklılaşıp farkıılaşmadığını saptamaktır. Araştırma ilişkisel tarama modeli ile yapılmıştır. Araştırmanın evreni 2019-2020 Eğitim Öğretim yılında İnönü Üniversitesi Eğitim Fakültesi Sosyal Bilgiler Öğretmenliği 2., 3. ve 4. sınıf öğrencilerinden oluşmaktadır. Evrenin tümüne ulaşııması amaçlanmıştır. Veri analizinde Mann Whitney $U$ ve Kruskal-Wallis $H$ Test kullanılmıştır. Araştırmada veri toplama aracı olarak Göksün (2016) tarafından geliştirilen 21. yüzyıl öğreten becerileri ölçeği ile 21. yüzyıl öğrenen becerileri ölçeği kullanılmıştır. Araştırma sonucunda öğretmen adaylarının öğrenen becerilerinde otonom, öğreten becerilerinde ise esnek öğretme becerilerinin sınıf düzeyine göre anlamlı düzeyde farklılaştığı görülmüştür.

Anahtar Kelimeler: Sosyal Bilgiler Öğretmeni Adayı, Öğreten Becerileri, Öğrenen Becerileri, 21. Yüzyıl Becerileri

Abstract: In the 21st century, where knowledge has rapidly increased and changed, social order and individual needs are also rapidly changing. However, new jobs and professions are emerging. The ability of countries to keep up with this new formation depends on their training of human potential as individuals who can meet the professional needs of the new century. This will be possible by implementing 21st century skills training programs, which are expected to meet the needs of the new century. The most important task here belongs to the teachers who will apply these training programs. For this reason, in order for the 21st century skills to be gained to the students, teachers with these skills must be trained first. In this direction, the aim of the research is to examine the level of pre-service teachers who will be both learners and teachers of the 21st century and to determine whether the level of possession of these skills differs according to gender and class variables. The research was done with relational screening model. The universe of the research consists of 2nd, 3rd and 4th grade students of Inonu University Faculty of Education Social Studies Teacher in 2019-2020 academic year. It is aimed to reach the entire universe. Mann Whitney $\mathrm{U}$ and Kruskal-Wallis $\mathrm{H}$ Test were used for data analysis. 21st century teacher skills scale and 21st 
Hasan Aydemir - Yalçın Karalı - Gökhan Coşanay

century learner skills scale developed by Göksün (2016) were used as data collection tools. As a result of the research, it has been observed that teacher candidates' autonomous learning skills and flexible teaching skills differ significantly compared to grade level.

Keywords: Social Studies Teacher Candidate, Teacher Skills, Learner Skills, 21st Century Skills

\section{GİRIŞ}

Yaşadığımız yüzyılda bilim ve teknoloji alanında meydana gelen hızlı değişim ve gelişim beraberinde toplumların sosyal yaşamlarını, bireylerin istek ve ihtiyaçlarını, öğrenme-öğretme faaliyetlerini (MEB, 2018: 3) ve eğitim durumlarını etkileyerek bireylerin sahip olması gereken beceri ve yeterliklerde çeşitli değişimlerin yaşanmasına sebep olmuştur (Cansoy, 2018: 2). Günümüz eğitim sisteminin öğrencisi olan 21. yüzyıl öğreneninden beklenen nitelikler kendisine hazır olarak sunulan bilgiyi olduğu gibi kabul edip ezberlemesi değil, her alanda bilgiye erişebilmesi ve eriştiği bilgileri çevresine fayda sağlayacak şekilde paylaşarak (Hamarat, 2019: 7) eğitim-öğretim ortamında ve gerçek hayatta karşılaşacağı sorunlarla başa çıkabilmek için kullanabilmesidir (Şeyma Büşra Bozkurt, 2016: 2).

Alan yazında daha çok "dijital yerli" (Prensky, 2001: 1) ve "yeni bin yılın öğrencisi" (Pedró, 2006: 2) olarak tanımlanan 21. yüzyıl öğrenenlerinin değişen dünya koşullarıyla birlikte gelişen teknolojilere uyum sağlayıp bu teknolojileri kullanabilecek becerilerle donatılmaları (EnGauge, 2003: 1), eğitim kurumlarının yeni yüzyıl öğrenenlerini "21. yüzyıl becerileri" olarak belirtilen eleştirel düşünme, problem çözme, iletişim ve işbirliği gibi becerilere sahip bir şekilde yetiştirmeleri beklenmektedir (Yalçın, 2018: 2). Türk Eğitim Sisteminin de bu doğrultuda dünya genelinde yaşanan gelişmeleri takip ederek sahip olduğu genç nüfusu doğru bir şekilde eğitip, onlara geleceğe uygun meslek alanları sunabilmek için amaca yönelik, güncel ve uzun vadeli eğitim politikaları ortaya koyabilmesi gerekmektedir (Tübitak, 2005: 8). Ancak bu eğitim politikalarını oluştururken teknolojinin insan yaşamına olan katkılarını göz önünde bulundurarak tamamen makineleşme odaklı bir eğitim içeriği oluşturmak tek doğru olarak kabul edilmemelidir (MEB, 2018: 7).

Milli Eğitim Bakanlığının 2023 vizyon belgesinde eğitimöğretimdeki asıl amacın içinde bulunduğumuz yüzyılın becerilerine 
sahip ve bu becerileri tüm insanlığa fayda sağlayacak ş̧ekilde kullanabilen ahlaklı, kültürlü ve donanımlı bireyler yetiştirmek olması gerektiği belirtilmektedir (MEB, 2018: 7). Bu amacı gerçekleştirebilmek için elbette en büyük sorumluluk 21. yüzyıl öğrenenlerini eğitecek olan bu yüzyılın öğretenlerine düşmektedir. 21. yüzyıl öğrenenlerini yetiştirecek olan yeni nesil öğretmenlerden beklenen, bilgiyi anlatan ve öğrencilerini klasik değerlendirme yöntemlerini kullanarak değerlendiren değil, eğitim-öğretim sürecini iyi planlayabilen, bu süreci doğru yönetebilen ve öğrencilerinin bireysel farklılıklarını dikkate alarak onları geleceğe hazırlayan iyi birer rehber olabilmeleridir (Göksün, 2016: 14). Ayrıca yeni yüzyıl öğretmenlerinin yaşanan teknolojik gelişmeleri yakından takip ederek bu gelişmeleri sınıfına taşıyabilen, aktif olarak kullanabilen, öğrencilerin de bu teknolojileri kullanabilmeleri için onlara bu süreçte rehberlik edebilen donanımlı bireyler olmaları gerekmektedir (Palfrey, 2008).

Konu ile ilgili ulusal ve uluslararası alan yazında yapılan çalışmalar incelendiğinde güncel olması ve yapılan birçok araştırmada ortak başvuru kaynağı olarak gösterilmeleri sebebiyle 21. yüzyıl öğrenen becerilerinin tanımlanmasında Ekonomik Kalkınma ve İşbirliği Organizasyonu (OECD), Uluslararası Eğitim Standartları Derneği (ISTE), Kuzey Merkez Bölgesel Eğitim Laboratuvarı (NCREL), 21. Yüzyıl Öğrenme Ortaklığı (P-21), Türkiye Yeterlikler Çerçevesi (TYÇ) ve Dünya Ekonomik Formu (WEF) tarafından alan yazına kazandırılmış becerilerin incelenmesi ve 21. yüzyıl öğreten becerilerinin tanımlanmasında ise MEB Genel Öğretmen Yeterliklerinin ve öğretmenler için ISTE standartlarının incelenmesi ve açıklanması uygun görülmüştür.

Türkiye'nin de kurucu üyeleri arasında yer aldığı OECD, 2018 yılında yapmış olduğu DeSeCo (Definition and Selection of Competencies-Yetkinliklerin Seçimi ve Tanımı) projesi ile yeni bin yılın öğrenenlerinin 2030'lu yıllarda sahip olması gereken becerileri "dönüştürücü yetkinlikler" olarak üç başlıkta ele almış ve bu başlıkları yeni değerler oluşturma, zorluk ve gerilimle başa çıkma ve sorumluluk alma olarak ifade etmiştir. Bu becerilere ilişkin öğrenme çerçevesini ise "yetkinlikler" olarak ifade etmiş ve bu yetkinlikleri bilgi, beceriler, tutum ve değerler olarak yine üç ana başlıkta ele almıştır. Bilgi kısmını kendi içerisinde; bir disipline ait bilgi, disiplinler arası bilgi, epistemik bilgi ve süreçsel bilgi olarak dört grupta incelerken, beceriler kısmını; 
Hasan Aydemir - Yalçın Karalı - Gökhan Coşanay

bilişsel ve biliş üstü beceriler, sosyal ve duygusal beceriler ve uygulamaya dönük beceriler olarak üç grupta ve son olarak tutum ve değerler kısmını ise kişisel, yerel, toplumsal ve küresel olarak dört grupta incelemiştir (OECD, 2018: 4). OECD tüm bu yetkinlikleri merkezine 21. yüzyıl becerileri ile donatılmış yeni yüzyıl öğrenenini alan ve çevresinde destek noktalar olarak aile, öğretmen, akran ve toplumdan oluşan güçlü bir yapının bulunduğu yön gösterici bir pusula sistemine benzetmiştir.

Kuzey Merkez Bölgesel Eğitim Laboratuvarı (NCREL) ise dünya genelinde yaşanan teknolojik gelişmeye dikkati çekerek 21. yüzyıl becerilerini dijital çağ okuryazarlığı (temel okur-yazarlık, bilimsel okuryazarlık, teknoloji okur-yazarlığı, görsel ve bilgi okur-yazarlığı, kültürel okur-yazarlık ile küresel okur-yazarlık), yenilikçi düşünme (karmaşık durumlara uyum sağlama, yönetme, öz-yönetim, merak, yaratıcılık, inisiyatif alma, üst düzey düşünme ve akıl yürütme), etkili iletişim (takım oluşturma, işbirliği, kişisel ve sosyal sorumluluk ile etkili iletişim) ve yüksek verimlilik (sonuç odaklı planlama yapma ve yürütme, gerçek yaşama ilişkin araç-gereç kullanma, nitelikli ürünler ve sonuçlar elde etme) olmak üzere dört ana başlıkta ve bunları da çeşitli alt başlıklar içinde açıklamıştır (EnGauge, 2003: 1-2).

Sayfa | 1203

Uluslararası Eğitim Standartları Derneği (ISTE-S) öğrencilerin içinde bulunduğumuz yüzyılda bilgi ve iletişim teknolojilerini nasıl kullanacaklarına ilişkin birtakım becerilere sahip olmaları gerektiğini vurgulamıştır (Cansoy, 2018: 11). ISTE, 21. Yüzyıl öğrenenleri için gerekli olduğunu düşündüğü bu becerileri yetkili öğrenci, dijital vatandaş, bilgi oluşturucu, yenilikçi tasarımcı, hesaplamalı düşünür, yaratıcı iletişimci ve global ortak çalışmacı olarak yedi başlık altında açıklamıştır (ISTE, 2016a: 1-2).

2015 yılında Dünya Ekonomik Formu (WEF) bir rapor yayınlamış ve bu raporda mesleklerin geleceği, iş gücü stratejileri ve beceriler üzerinde durularak yeni eğitim vizyonunda sahip olunması gereken 16 önemli beceri olduğunu belirtmiştir. WEF bu becerileri temel okuryazarlıklar (okuryazarlık, matematik, bilgi okuryazarlığı, bilgi ve iletişim teknolojileri okuryazarlığı, finansal okuryazarlık ile kültürel ve vatandaşlık okuryazarlığı), yetkinlikler (eleştirel düşünme ve problem çözme, yaratıcılık, iletişim ve işbirliği) ve karakter özellikleri (merak etme, girişimcilik, azim, uyum sağlama, liderlik ile sosyal ve kültürel 
Hasan Aydemir - Yalçın Karalı - Gökhan Coşanay

farkındalık) olarak üç ana başlık ve bu başlıkları da kendi içerisinde çeşitli alt başlıklar halinde açıklamıştır (World Economic Forum, 2015: 4).

Amerika Birleşik Devletleri'nde 21 eyalette uygulanan ve 33 kurum, çok sayıda eğitim uzmanı ile iş dünyasından insanın katılımıyla desteklenen eğitim projesi olan "Partnership for 21st Century Learning [P21] / 21. Yüzyıl Öğrenme Ortaklığı" adlı projede 21. yüzyıl öğrenenlerinin sahip olması gereken beceriler "21. Yüzyıl Öğrenme Çerçevesi" başlığı altında incelenmiştir (P21, 2019: 1). Bu öğrenme çerçevesi 21. yüzyıl becerilerini; öğrenme ve yenilik becerileri (yaratıcılık ve yenilik, eleştirel düşünme ve problem çözme, işbirliği, iletişim), bilgi-medya ve teknoloji becerileri (bilgi okuryazarlığı, medya okuryazarlığı, teknoloji okuryazarlığı) ile yaşam ve kariyer becerileri (esneklik ve uyum, girişimcilik ve öz-yönelim, sosyal ve kültürlerarası beceriler, üretkenlik ve mesuliyet, liderlik ve sorumluluk) olarak üç ana başlık ve başlıkların her birini de kendi içerisinde alt başlıklar halinde açıklamıştır (P21, 2019: 1-2). Bu beceriler yaşadığımız yüzyılın anahtar konuları olarak kabul edilen dil edinimi, okuma ve dil sanatları, dünya dilleri, sanat, matematik, fen/bilim, coğrafya, tarih, devlet ve vatandaşlık temalarına dayandırılmış ve bu temalara bağlı olarak küresel farkındalık, mali, ekonomik, iş dünyası ve girişimcilik ile ilgili okuryazarlık, sivil okuryazarlık, sağlık okuryazarlığı ile çevre okuryazarlığını içeren disiplinler arası temalar oluşturulmuştur. Bütün bu beceriler, anahtar konular ve disiplinler arası temalar ise "21. yüzyıl destek sistemleri" olarak adlandırılan; 21. yüzyıl standartları ve değerlendirme, 21. yüzyıl müfredatı ve öğretimi, 21. yüzyıl mesleki gelişimi ve 21. yüzyıl öğrenme çevresi üzerine şekillendirilmiştir (Gelen, 2017: 23).

Uluslararası alanda yaşanan bu gelişmeler doğrultusunda Avrupa Yeterlik Çerçevesine paralel olarak oluşturulan Türkiye Yeterlikler Çerçevesinde (TYÇ) de "Hayat Boyu Öğrenme İçin Anahtar Yetkinlikler" olarak tanımlanan sekiz yetkinlik alanı literatüre kazandırılmıştır. Bu yetkinlikler; anadilde iletişim, yabancı dillerde iletişim, matematiksel yetkinlik ve bilim/teknolojideki temel yetkinlikler, dijital yetkinlik, öğrenmeyi öğrenme, sosyal ve vatandaşlıkla ilgili yetkinlikler, inisiyatif alma ve girişimcilik ile kültürel farkındalık ve ifade olarak sıralanmaktadır (Türkiye Yeterlikler Çerçevesi, 2015: 23-25). 
Literatürde tanımlanan bu becerilerin 21. yüzyıl öğrenenlerine kazandırılmasında büyük görev düşen öğretmenlerin sahip olması gereken 21. yüzyı öğreten becerileri ise Milli Eğitim Bakanlığı'nın (MEB) öğretmenlik mesleği yeterlik çalışmaları ile ilgili yaptığı güncellemeler sonucunda "mesleki bilgi", "mesleki beceri", "tutum ve değerler" olarak üç ana başlık altında ele alınmıştır. Mesleki bilgiyi; alan bilgisi, alan eğitim bilgisi ve mevzuat bilgisi diye üç alt grupta, mesleki beceriyi; eğitim-öğretimi planlama, öğrenme ortamları oluşturma, öğrenme ve öğretme sürecini yönetme, ölçme ve değerlendirme olarak dört alt grupta ve tutum ve değerleri ise milli, manevi ve evrensel değerler, öğrenciye yaklaşım, iletişim ve iş birliği, kişisel ve mesleki gelişim olarak dört alt grupta açıklamıştır (MEB, 2017: 13-16).

Uluslararası Eğitim Standartları Derneği (ISTE) ise yaşadığımız yüzyılda öğretmenlerin bir takım standartlara sahip olması gerektiğini belirtmiş olup bu standartlara sahip öğretmen niteliklerini öğrenen, öğrencilerine liderlik yapan, dijital dünyaya katkı sunmalarını sağlayan bir vatandaş olan, yaratıcl, hem öğrencileri hem de meslektaşları ile işbirliği yapan, teknoloji ile öğrenmeyi kolaylaştıran ve elindeki verileri çözümleyen bireyler olarak tanımlamıştır (ISTE, 2016b: 1-2).

\section{YÖNTEM}

Bu araştırmada ilişkisel tarama modeli kullanılmıştır. Tarama araştırmaları geçmişte ya da hâlihazırda var olan bir durumu olduğu gibi betimlemeyi amaçlayan araştırma modelidir (Karasar, 2016: 109). Ayrıca tarama araştırmaları ilişkilerin belirlenmesini ve araştırmacının tahminde bulunmasını sağlar. Amaç mevcut durumu anlayıp daha iyi yorumlayabilmektir. İlişkileri ve bağlantıları inceleyen araştırmalar ilişkisel araştırmalar olarak adlandırılır (Büyüköztürk vd., 2010: 22).

\section{ÇALIŞMA GRUBU}

Araştırmanın evrenini İnönü Üniversitesi Eğitim Fakültesi Sosyal Bilgiler Öğretmenliği Program'ında öğrenim gören 2., 3. ve 4. sınıf öğrencileri oluşturmaktadır. 1.sınıflar henüz yükseköğretime başlamış olmaları ve yeterli düzeyde öğretmenlik meslek bilgisine ilişkin ders almamış olmaları sebebiyle çalışma grubuna dahil edilmemiştir. Evrenin tümüne ulaşılması amaçlandığından örneklemeye gidilmemiştir. Öğrenim gören tüm öğrencilere ulaşılmış ve yeterli koşullarını taşıyan 143 ölçek değerlendirmeye alınmıştır. 
Hasan Aydemir - Yalçın Karalı - Gökhan Coşanay

\section{VERİ TOPLAMA ARAÇLARI}

Araştırmada veriler Göksün (2016) tarafından geliştirilen "21. Yüzyıl Öğreten ve Öğrenen Becerileri Kullanım Ölçeği" ile toplanmıştır. Veri seti normal dağılım göstermediğinden iki kategorili değişkenler için Mann-Whitney U Testi, üç kategorili değişkenler için ise Kruskal-Wallis $\mathrm{H}$ Testi kullanılmıştır.

\section{BULGULAR}

Sosyal bilgiler öğretmen adaylarının 21. yüzyıl öğrenen ve öğreten becerileri alanlarına ilişkin betimsel istatistikler Tablo 1'de verilmiştir.

Tablo 1: 21. Yüzyıl Öğrenen ve Öğreten Becerileri Alanlarına İlişkin Betimsel İstatistikler

\begin{tabular}{lcccc}
\hline Beceri Alanı & $\bar{X}$ & $\begin{array}{c}\text { Standart } \\
\text { Sapma }\end{array}$ & En yüksek & En düşük \\
\hline Öğreten & 4,12 &, 473 & 4,89 & 2,11 \\
\hline Yönetsel & 4,23 &, 557 & 5,00 & 1,58 \\
\hline Teknopedogojik & 3,85 &, 506 & 5,00 & 2,13 \\
\hline Onamacı & 4,76 &, 368 & 5,00 & 3,00 \\
\hline Esnek Öğretme & 3,65 &, 870 & 5,00 & 1,00 \\
\hline Üretimsel & 4,03 &, 862 & 5,00 & 1,50 \\
\hline Öğrenen & 3,94 &, 445 & 4,74 & 2,45 \\
\hline Bilişsel & 4,23 &, 445 & 5,00 & 2,65 \\
\hline Otonom & 3,60 &, 663 & 5,00 & 2,33 \\
\hline İş Birliği ve Esneklik & 3,52 &, 746 & 4,83 & 1,17 \\
\hline Yenilikçilik & 3,88 &, 845 & 5,00 & 1,00 \\
\hline
\end{tabular}

Tablo 1'de görüldüğü üzere Sosyal bilgiler öğretmen adaylarının 21. yüzyıl öğreten becerilerini kullanımlarının ortalaması $\bar{X}_{21 . y y \text {.ögretenbecerileri }}=4,12$ olup; öğreten becerilerinin alt boyutlarını kullanımları büyükten küçüğe doğru onamacı beceriler $\left(\bar{X}_{\text {onamacıbeceriler }}=\right.$ $4,76)$, yönetsel beceriler ( $\left.\bar{X}_{\text {yönetselbeceriler }}=4,23\right)$, üretimsel beceriler $\left(\bar{X}_{\text {üretimselbeceriler }}=4,03\right)$, teknopedagojik beceriler $\left(\bar{X}_{\text {teknopedagojikbeceriler }}=\right.$ 3,85 ) ve esnek öğretme becerileri ( $\bar{X}_{\text {esneköğretme }}=3,65$ ) olarak sıralanmaktadır. 21. yüzyı öğrenen becerileri kullanım ortalamaları ise

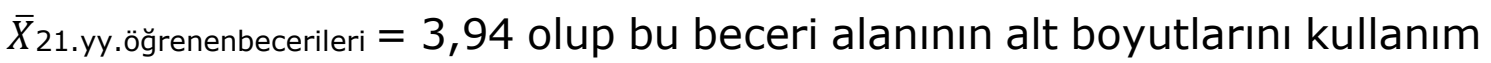
düzeyleri sırasıyla bilişsel beceriler $\left(\bar{X}_{\text {bilişselbeceriler }}=4,23\right)$, yenilikçilik becerileri $\left(\bar{X}_{\text {yenilikçilikbecerileri }}=3,88\right)$, otonom beceriler $\left(\bar{X}_{\text {otonombeceriler }}=\right.$ $3,60)$ ve iş birliği ve esneklik becerileri $\left(\bar{X}_{\text {işbirliğiveesneklikbecerileri }=3,52)}\right.$ olarak sıralanmaktadır. Öğretmen adaylarının 21. yüzyıl öğrenen ve öğreten becerilerine ait her bir ölçeğin en yüksek ve en düşük değerlerine bakıldığında en yüksek değerler arasında en düşük ortalama 4,74 ile öğrenen becerilerine aitken; en düşük değerler 
arasında en yüksek ortalama 3,00 ile onamacı becerilere aittir. Ayrıca en düşük standart sapma değeri ,368 ile onamacı becerilerde iken, en yüksek standart sapma değeri ,870 ile esnek öğretme becerilerine aittir.

Sosyal bilgiler öğretmen adaylarının 21. yüzyıl öğrenen becerilerinin alt boyutlarının cinsiyete göre Mann-Whitney U Testi sonuçları Tablo 2'de yer almaktadır.

Tablo 2: 21. Yüzyıl Öğrenen Becerilerinin Cinsiyete Göre Mann-Whitney U Testi Sonuçları

\begin{tabular}{clccccc}
\hline $\begin{array}{c}\text { Beceri } \\
\text { Alanı }\end{array}$ & Cinsiyet & $\mathrm{n}$ & $\begin{array}{c}\text { Sıra } \\
\text { Ortalaması }\end{array}$ & $\begin{array}{c}\text { Sıra } \\
\text { Toplamı }\end{array}$ & $\mathrm{U}$ & $\mathrm{p}$ \\
\hline \multirow{2}{*}{ Bilişsel } & Kız & 96 & 69,78 & 6699 & \multirow{2}{*}{2043} & \multirow{2}{*}{359} \\
& Erkek & 47 & 76,53 & 3597 & & \\
\hline \multirow{2}{*}{ Otonom } & Kız & 96 & 68,46 & 6572 & \multirow{2}{*}{1916} & \multirow{2}{*}{143} \\
& Erkek & 47 & 79,23 & 3724 & & \\
\hline \multirow{2}{*}{ İş Birliği ve } & Kız & 96 & 71,92 & 6904 & \multirow{2}{*}{2248} & \multirow{2}{*}{974} \\
Esneklik & Erkek & 47 & 72,16 & 3391 & & \multirow{2}{*}{256} \\
\hline \multirow{2}{*}{ Yenilikçilik } & Kız & 96 & 69,31 & 6654 & \multirow{2}{*}{1998} & \multirow{2}{*}{ Erkek } \\
& 47 & 77,49 & 3642 & & &
\end{tabular}

Tablo 2'de Sosyal bilgiler öğretmen adaylarının 21. yüzyıl öğrenen becerilerinin bilişsel, otonom, iş birliği ve esneklik ve yenilikçilik becerileri alt boyutlarında cinsiyet açısından anlamlı bir farklılaşma olmadığı görülmektedir.

Sosyal bilgiler öğretmen adaylarının 21. yüzyıl öğreten becerilerinin alt boyutlarının cinsiyete göre Mann-Whitney U Testi sonuçları Tablo 3'te yer almaktadır.

Tablo 3: 21. Yüzyıl Öğreten Becerilerinin Cinsiyete göre Mann-Whitney U Testi Sonuçları

\begin{tabular}{|c|c|c|c|c|c|c|}
\hline Beceri Alanı & Cinsiyet & $\mathrm{n}$ & $\begin{array}{c}\text { Sıra } \\
\text { Ortalaması }\end{array}$ & $\begin{array}{c}\text { Sira } \\
\text { Toplamı }\end{array}$ & $U$ & $p$ \\
\hline \multirow{2}{*}{ Yönetsel } & $\mathrm{KIZ}$ & 96 & 73,31 & 7037 & \multirow{2}{*}{2130} & \multirow{2}{*}{,589 } \\
\hline & Erkek & 47 & 69,33 & 3258 & & \\
\hline \multirow{2}{*}{ Teknopedagojik } & $\mathrm{KIZ}$ & 96 & 70,12 & 6731 & \multirow{2}{*}{2075} & \multirow{2}{*}{,436 } \\
\hline & Erkek & 47 & 75,84 & 3564 & & \\
\hline \multirow{2}{*}{ Onamacı } & $\mathrm{KIZ}$ & 96 & 71,91 & 6903 & \multirow{2}{*}{2247} & \multirow{2}{*}{,967 } \\
\hline & Erkek & 47 & 72,18 & 3392 & & \\
\hline Üretimsel & $\begin{array}{c}\text { KIz } \\
\text { Erkek }\end{array}$ & $\begin{array}{l}96 \\
47 \\
\end{array}$ & $\begin{array}{l}76,47 \\
62,87 \\
\end{array}$ & $\begin{array}{l}7341 \\
2955 \\
\end{array}$ & 1827 & ,059 \\
\hline \multirow{2}{*}{ Esnek Öğretme } & $\mathrm{KIZ}$ & 96 & 74,18 & 7121 & \multirow{2}{*}{2046} & \multirow{2}{*}{,356 } \\
\hline & Erkek & 47 & 67,54 & & & \\
\hline
\end{tabular}


Tablo 3'te Sosyal bilgiler öğretmen adaylarının 21. yüzyıl öğreten becerilerinin yönetsel, teknopedagojik, onamacı, üretimsel ve esnek öğretme becerileri alt boyutlarında cinsiyet açısından anlamlı bir farklılaşma olmadığı görülmektedir.

Sosyal bilgiler öğretmen adaylarının 21. yüzyıl öğrenen becerilerinin alt boyutlarının sınıf düzeyine göre Kruskal-Wallis H Testi sonuçları Tablo 4'te yer almaktadır.

Tablo 4: 21. Yüzyıl Öğrenen Becerilerinin Sınıf Düzeyine göre Kruskal-Wallis H Testi Sonuçları

\begin{tabular}{cccccccc}
\hline $\begin{array}{c}\text { Beceri } \\
\text { Alanı }\end{array}$ & $\begin{array}{c}\text { Sınıf } \\
\text { Düzeyi }\end{array}$ & $\mathrm{n}$ & Sıra Ort. & Ss & $\mathrm{X}^{2}$ & $\mathrm{P}$ & $\begin{array}{c}\text { Anlamlı } \\
\text { fark }\end{array}$ \\
\hline \multirow{3}{*}{ Bilişsel } & 2 & 58 & 75,84 & & & & \\
& 3 & 42 & 78,05 &, 445 & 4,487 &, 106 & \\
& 4 & 43 & 60,91 & & & & \\
Otonom & 2 & 58 & $\mathbf{6 0 , 8 4}$ & & & & \\
& 3 & 42 & 74,02 &, 663 & 8,635 &, $\mathbf{0 1 3}$ & $\mathbf{4 - 2}$ \\
\hline İş Birliği & 4 & 43 & $\mathbf{8 5 , 0 7}$ & & & & \\
ve & 3 & 58 & 64,10 & & & & \\
Esneklik & 4 & 43 & 83,12 &, 746 & 5,164 &, 076 & \\
\hline \multirow{2}{*}{ Yenilikçilik } & 2 & 58 & 71,79 & & & & \\
& 3 & 42 & 78,05 & & & & \\
& 4 & 43 & 66,20 &, 845 & 1,811 &, 404 & \\
\hline
\end{tabular}

Tablo 4'te görüldüğü üzere Sosyal bilgiler öğretmen adaylarının 21. yüzyıl öğrenen becerilerinin bilişsel, iş birliği ve esneklik ile yenilikçilik beceri alanlarında sınıf düzeylerinde anlamlı bir farklılaşma bulunmamaktadır. Otonom beceri alanında ise $p=, 013<, 05^{\prime}$ ten olduğu için sınıf düzeylerinde anlamlı bir farklılaşma bulunmaktadır. Bu farklılaşma 4. ve 2. sınıflar arasında olup, 2. Sınıfların sıra ortalaması $60,84,4$. sınıfların sıra ortalaması ise 85,07 olduğundan farklılaşma 4. sınıflar lehinedir.

Tablo 5: 21. Yüzyıl Öğreten Becerilerinin Sınıf Düzeyine göre Kruskal-Wallis H Testi Sonuçları

\begin{tabular}{cccccccc}
\hline Beceri Alanı & $\begin{array}{c}\text { Sınıf } \\
\text { Düzeyi }\end{array}$ & $\mathrm{n}$ & $\begin{array}{c}\text { Sıra } \\
\text { Ort. }\end{array}$ & Ss & $\mathrm{X}^{2}$ & $\mathrm{P}$ & $\begin{array}{c}\text { Anlamlı } \\
\text { fark }\end{array}$ \\
\hline \multirow{3}{*}{ Yönetsel } & 2 & 58 & 72,44 & & & & \\
& 3 & 42 & 80,94 &, 557 & 4,161 &, 125 & \\
& 4 & 43 & 62,67 & & & & \\
\hline \multirow{3}{*}{ Teknopedagojik } & 2 & 58 & 69,53 & & & & \\
& 3 & 42 & 79,89 &, 506 & 2,229 &, 328 & \\
\hline \multirow{2}{*}{ Onamacl } & 4 & 43 & 67,62 & & & & \\
& 2 & 58 & 73,76 & & & & \\
& 3 & 42 & 77,23 &, 368 & 2,843 &, 241 & \\
\hline
\end{tabular}


Hasan Aydemir - Yalçın Karalı - Gökhan Coşanay

\begin{tabular}{clllllll}
\hline \multirow{2}{*}{ Esnek Öğretme } & 2 & 58 & 74,66 & & & & \\
& 3 & 42 & $\mathbf{8 1 , 5 6}$ &, 870 & 6,984 &, $\mathbf{0 3 0}$ & $\mathbf{3 - 4}$ \\
& 4 & 43 & $\mathbf{5 9 , 0 8}$ & & & & \\
\hline \multirow{2}{*}{ Üretimsel } & 2 & 58 & 70,98 & & & & \\
& 3 & 42 & 81,33 &, 862 & 3,846 &, 106 & \\
\hline
\end{tabular}

Tablo 5'te görüldüğü üzere Sosyal bilgiler öğretmen adaylarının 21. yüzyıl öğreten becerilerinin yönetsel, teknopedagojik, onamacl ve esnek öğretme beceri alanlarının sınıf düzeylerinde herhangi bir farklılaşma bulunmamaktadır. Esnek öğretme beceri alanında ise $p=$ , $030<, 05$ ' ten olduğu için sınıf düzeyleri arasında anlamlı bir farklılaşma bulunmaktadır. Bu farklılaşma 3. ve 4. sınıflar arasında olup 3. sınıfların ortalaması $81,56,4$. Sınıfların ortalaması ise 59,08 olduğu için farklılaşma 3. sınıflar lehinedir.

\section{SONUÇ VE TARTIŞMA}

Yapılan araştırmada Sosyal bilgiler öğretmen adaylarının 21. yüzyı öğreten becerileri ve 21. yüzyıl öğrenen becerileri kullanımları Göksün (2016) tarafından geliştirilen "21. yüzyıl Öğreten Becerileri ve Öğrenen Becerileri Kullanım Ölçeği" çerçevesinde ölçülmüştür. 21. yüzyıl öğreten becerileri; yönetsel beceriler, teknopedagojik beceriler, onamacı beceriler, esnek öğretme becerileri ve üretimsel beceriler olarak beş alt boyutta; 21. yüzyıl öğrenen becerileri ise bilişsel beceriler, otonom beceriler, iş birliği ve esneklik becerileri ve yenilikçilik becerileri olarak dört alt boyutta ele alınmıştır.

Sosyal bilgiler öğretmen adaylarının 21. yüzyıl öğrenen becerileri ve tüm alt beceri alanlarını kullanımlarının orta düzeyin üzerinde olduğu görülmüştür. Şahin (2010) tarafından gerçekleştirilen araştırma sonucunda öğretmen adaylarının yaklaşık \%60'ının yeni bin yılın öğrenen özelliklerini taşıdığı, özellikle bilişsel beceriler alanında daha olumlu sonuçlar elde edildiği görülmektedir. Göksün (2016) tarafından yapılan araştırmada öğretmen adaylarının 21. yüzyıl öğrenen becerilerini kullanımlarının orta düzeyin üzerinde olduğu ve en çok kullandıkları beceri alanının ise bilişsel beceriler olduğu görülmektedir. Kıyasoğlu (2019) tarafından yapılan araştırmada ise sınıf öğretmenlerinin 21 . yüzyıl öğrenen becerilerini kullanımlarının genel olarak iyi düzeyde olduğu, en yüksek düzeydeki beceri alanının ise bilişsel beceriler olduğu görülmektedir. Bu sonuçlar sosyal bilgiler öğretmen adaylarının öğrenen becerilerini kullanım düzeyleri ilgili araştırma sonuçları ile paralellik göstermektedir. Ayrıca öğretmen 
adaylarının bu beceri alanlarından en çok bilişsel becerileri kullandıkları ve bilişsel becerilerin standart sapmasının diğer beceri alanlarına göre en düşük değerler arasında yer aldığı, öğretmen adaylarının bu beceri alanını kullanma düzeylerinin birbirine çok yakın olduğu ve ölçeğin uygulandığı grubun bu alanda başarılı olduğu şeklinde yorumlanabilir. Young (2012) bu durumu öğreticilerin 21. yüzyıl öğrenenlerine hala eski dönemden kalma eğitim-öğretim etkinliklerini uygulayarak sadece bilişsel becerilerini aktifleştirebilmeleri ile açıklamıştır. Bu açıklamaya göre en çok kullanılan becerilerin bilişsel beceriler olması öğretenlerin geleneksel öğretim uygulamalarını kullanmalarından kaynaklandığını gösterebilir. Sosyal bilgiler öğretmen adaylarının 21. yüzyıl öğrenen becerileri arasında en az kullandıkları beceri alanının ise iş birliği ve esneklik becerileri olduğu gözükmektedir. Bu durum geçmişte eğitim sistemlerinde belirgin olan öğretmen merkezli yaklaşımların bireylerin kişisel başarılarını dikkate alarak, ödül-ceza sistemine göre kişilerarası rekabetin ön planda olduğu eğitim-öğretim ortamları oluşturarak iş birliği ve esneklik becerilerinin gelişimini sınırlandırması ile açıklanabilir.

Sosyal bilgiler öğretmen adaylarının 21. yüzyıl öğreten becerileri ve alt beceri alanlarına ilişkin kullanımlarının iyi düzeyde olduğu görülmektedir. Araştırma içeriğine alınan öğreten becerilerinin 21 . yüzyıl eğitimi kapsamında oluşturulduğu dikkate alındığında yeni nesil öğretmen adaylarının öğreten becerilerini mesleki yaşamlarında kolaylıkla uygulayabilecekleri ve 21 . yüzyıl öğrenenlerinden oluşan öğrencilerine bu becerileri kazandırmanın üstesinden gelebilecekleri şeklinde değerlendirilebilir. Bunker (2012), günümüz öğretmenlerinin kullanmış olduğu öğretmen merkezli yaklaşımların öğrencilerin 21 . yüzyıl becerilerinin gelişimine katkı sağlamayacağını, bu nedenle öğrenci merkezli yaklaşımların uygulanması gerektiği belirtmektedir. Sosyal bilgiler öğretmen adaylarının 21. yüzyıl öğrenen becerilerine paralel olarak öğreten becerilerini kullanımlarının iyi düzeyde olması meslek hayatlarında öğrenci merkezli yaklaşımları ön planda tutabilecekleri şeklinde yorumlanabilir. Sosyal bilgiler öğretmen adaylarının iyi düzeyde öğreten becerileri kullanımları Kıyasoğlu (2019) ve Göksün (2016) tarafından yapılan çalışma sonuçlarıyla da benzerlik göstermektedir. Sosyal bilgiler öğretmen adaylarının en çok kullandıkları beceri alanının onamacı beceriler olduğu görülmektedir. Ayrıca onamacı beceriler standart sapma değeri en düşük beceri alanı olarak görülmekte ve bu durum öğretmen adaylarının onamacı 
becerileri kullanım düzeylerinin birbirine çok yakın olduğuna ve kullanma düzeylerinin yüksek olduğuna işaret etmektedir. Türk eğitim sisteminde 2004 yılından itibaren uygulanmaya başlayan yapılandırmacı yaklaşımla öğrenme ortamlarının baskıcı, otoriter ve yargılayan değil; demokratik, karşılıklı sevgi-saygı esasına dayalı, destekleyici ortamlara dönüşmesi ve mevcut öğretmen adaylarının bu süreç içerisinde eğitim alması onamacı becerileri kullanım düzeylerinin yüksek olmasını açıklayabilir. Göksün (2016) tarafından yapılan araştırma sonuçlarının bu durumu desteklediği görülmektedir. Sosyal bilgiler öğretmen adaylarının 21. yüzyı öğreten becerileri arasında en az kullandıkları beceri alanlarının esnek öğretme becerileri olduğu görülmüştür. Öğretmen adaylarının esnek öğretme becerilerini kullanımlarının diğer beceri alanlarına göre daha düşük düzeyde olması kendi öğrencilik yaşamlarında okul dışı öğretim etkinliklerinin çok fazla kullanılmadığı, dolayısıyla bu beceri alanını çok fazla dikkate almadıklarını göstermektedir. Nitekim Kıyasoğlu (2019) tarafından yapılan araştırma sonucunda sınıf öğretmenlerinin esnek öğretme becerilerini diğer beceri alanlarına göre daha az kullanmaları bu yorumu desteklemektedir. Ayrıca Göksün (2016)'ün çalışmasında ifade ettiği ve çalışma sonucunda doğruladığı "öğretmen adaylarının kendi öğrenmelerine paralel öğrettikleri" ifadesi de bu sonucu desteklemektedir.

Sosyal bilgiler öğretmen adaylarının 21. yüzyıl öğrenen becerilerinin bilişsel, otonom, iş birliği ve esneklik ve yenilikçilik becerileri alt boyutlarında cinsiyet açısından herhangi bir farklılaşma olmadığı görülmüştür. Bu durum tüm öğretmen adaylarının öğrenen becerilerini kullanım düzeylerinin yakın seviyelerde olduğunu göstermektedir. Bununla birlikte 21. yüzyıl öğreten becerilerinin yönetsel, teknopedagojik, onamacı, üretimsel ve esnek öğretme becerileri alt boyutlarında cinsiyet açısından herhangi bir farklılaşma olmadığı görülmektedir. Dolayısıyla öğretmen adaylarının öğreten becerilerini kullanım düzeylerinin yakın seviyelerde olduğu görülmektedir.

Sosyal bilgiler öğretmen adaylarının 21. yüzyıl öğrenen becerilerinin bilişsel, iş birliği ve esneklik ile yenilikçilik alt beceri alanlarında sınıf düzeylerinde anlamlı bir farklılaşma bulunmamıştır. Otonom alt beceri alanında ise 4. sınıflar lehine anlamlı bir farklılaşma olduğu görülmektedir. Otonom becerilerin bağımsız düşünme, sorunlarla tek başına başa çıkabilme, grup çalışmalarında bağımsız 
Hasan Aydemir - Yalçın Karalı - Gökhan Coşanay

çalışmayı tercih etme gibi bireysel özerkliği içeren becerileri kapsaması 4. sınıftaki öğretmen adaylarının 2. sınıf öğretmen adaylarına göre özgüveni yüksek ve daha özerk kişilik yapısına sahip oldukları şeklinde yorumlanabilir. Pavia (2005)'in otonom öğrenme becerilerinin geliştirilmesinde öğrenenlerin içinde bulundukları sosyal, ekonomik ve eğitsel ortamların etkili olduğu ifadesi de bu yorumu desteklemektedir. Bu doğrultuda 4. sınıf öğrencilerinin 2. sınıflardan daha fazla sürede üniversitede ortamında bulunmalarının 4. sınıf öğretmen adaylarının otonom öğrenme becerilerini kullanım düzeylerinin daha yüksek olmasının sebebi olarak gösterilebilir.

Sosyal bilgiler öğretmen adaylarının 21. yüzyıl öğreten becerilerinin yönetsel, teknopedagojik, onamacl ve esnek öğretme alt beceri alanlarının sınıf düzeylerinde anlamlı bir farklılaşma olmadığı görülmüştür. Esnek öğretme alt beceri alanında ise 3. sınıflar lehine anlamlı farklılaşma olduğu görülmüştür. Esnek öğretme becerilerinin 3 . sınıf öğretmen adaylar lehine olması ise başlangıçta yüksek düzeyde olan sınıf dışı öğrenme-öğretme faaliyetleri düzenleme isteklerinin 4. sınıfa gelindiğinde düştüğünü göstermektedir. Öğretmen adaylarının lisans eğitimlerinin ilk yıllarda yoğun içerik bilgisine yönelik dersler alması sonucu okul dışı eğitim faaliyetleri düzenlemenin öğrenciler için öğrenmeyi kolaylaştıran bir aktivite olduğunu görmeleri ilk yıllarda bu beceri alanının kullanım düzeyinin yüksek çıkmasını sağlarken 4. sınıfa geldiklerinde almış oldukları okul uygulamaları dersleri sonrasında okul dışı eğitim faaliyetleri düzenlemenin prosedür olarak uzun ve sorumluluk gerektiren bir işlem olduğunu görmelerinin isteklerinde azalmaya yol açtığı şeklinde yorumlanabilir.

\section{ÖNERİLER}

$\mathrm{Bu}$ araştırmada elde edilen sonuçlar doğrultusunda aşağıdaki öneriler sunulabilir

1- Öğretmen adaylarının 21. yüzyıl öğrenen becerilerine yönelik olarak bilişsel becerilerinin yanı sıra iletişim ve iş birliği becerilerinin geliştirilmesi için uygun öğrenme ortamları oluşturularak grup etkinliklerine yer verilebilir.

2- Okul ortamında öğretmenlerin esnek öğretme becerilerini kullanım düzeyini arttırmak amacıyla esnek öğretme sürecini kolaylaştırıcı ve sürece teşvik edici imkanlar sağlanabilir.

3- 21. yüzyıl öğretenlerinin eğitimde dijital platformları aktif olarak kullanabilmesi ve teknopedagojik becerilerinin gelişmesi için 
Hasan Aydemir - Yalçın Karalı - Gökhan Coşanay

lisans programlarında bilgi ve iletişim teknolojileri kullanımlarına yönelik ders sayısı ve süresi arttırılabilir.

4- Araştırmanın örneklemini öğretmen adayları oluşturmaktadır. Görevde olan öğretmenlerin 21. yüzyıl öğrenen ve öğreten becerilerini kullanım düzeylerini belirlemek ve bazı değişkenler açısından incelemek için çalışan öğretmenlerden veri toplanarak bu becerileri kullanım düzeyleri incelenebilir.

\section{KAYNAKÇA}

Büyüköztürk, Ş., Çakmak, E. K., Akgün, Ö. E., Karadeniz, Ş. \& Demirel, F. (2010). Bilimsel Araştırma Yöntemleri. Ankara: Pegem Akademi.

Cansoy, R. (2018). Uluslararası Çerçevelere Göre 21. Yüzyıl Becerileri ve Eğitim Sisteminde Kazandırılması. Insan ve Toplum Bilimleri Araştırma Dergisi, 3112-3134.

EnGauge. (2003). 21st Century Skills for 21st Century Learners. Erişim Adresi: https://www.cwasd.k12.wi.us/highschl/newsfile1062_1.pdf.

Gelen, İ. (2017). P21- Program ve Öğretimde 21. Yüzyıl Beceri Çerçeveleri (ABD Uygulamaları). Disiplinlerarası Eğitim Araştırmaları Dergisi, 15-29.

Göksün, D. O. (2016). Öğretmen Adaylarının 21. Yüzyıl Öğrenen Becerileri ve 21. Yüzyıl Öğreten Becerileri Arasındaki İlişki. Eskişehir. Hamarat, E. (2019). 21. Yüzyıl Becerileri Odağında Türkiye'nin Eğitim Politikaları. İstanbul: Seta Yayıncılık.

ISTE. (2016a). ISTE Standards For Student. International Society for Technology in Education.

ISTE. (2016b). Erişim Adresi: https://www.iste.org/standards/foreducators. Erişim Adresi: https://www.iste.org/standards/foreducators.

Karasar, N. (2016). Bilimsel Araştırma Yöntemi. Ankara: Nobel Yayın Dağıtım.

MEB. (2012). Öğretmenlik Mesleği Genel Yeterlikleri. Milli Eğitim Bakanlığı.

MEB. (2017). Öğretmenlik Mesleği Genel Yeterlikleri. Ankara: MEB.

MEB. (2018). 2023 Eğitim Vizyonu. Ankara: Milli Eğitim Bakanlığı.

MEB. (2018). T.C . Milli Eğitim Bakanlığı Sosyal Bilgiler Dersi Öğretim Programı. Ankara: MEB. 
Hasan Aydemir - Yalçın Karalı - Gökhan Coşanay

Mesleki Yeterlilik Kurumu. (2015). Türkiye Yeterlikler Çerçevesi. Ankara.

OECD . (2018). The Future of Education and Skills: Educatin 2030. The Organization for Economic Co-operation and Development.

P21. (2019). The Partnership for 21st Century Learning.

Paiva, V. L. (2005). Autonomy and complexity. Share Magazine Online.

No. 146.

Erişim

Adresi:

http://www.acarindex.com/dosyalar/makale/acarindex-

1423878889.pdf. Erişim Tarihi: 08.03.2020.

Palfrey, J. a. (2008). Childhood in the Digital Age Born digital: Understanding the first generation of digital. International Journal of Communication, 1051-1055. Erişim Adresi: http://www.open.edu/openlearn.

Pedró, F. (2006). The New Mıllennium Learners:Challenging our Views on ICT and Learning.

Prensky, B. M. (2001). Digital Natives, Digital Immigrants.

Şeyma Büşra Bozkurt, H. Ç. (2016). Ortaokul Öğrencilerinin 21. Yüzyıl Öğrenme Beceri Düzeylerinin Cinsiyet ve Sınıf Seviyesine Göre İncelenmesi. Pamukkale Üniversitesi Eğitim Fakültesi Dergisi, 69-82. TED. (2009). Öğretmen Yeterlikleri. Ankara: Türk Eğitim Derneği. TÜBİTAK. (2005). Vizyon 2023 Teknoloji Öngörü Projesi Eğitim ve Insan Kaynakları Sonuç Raporu ve Strateji Belgesi. Ankara.

World Economic Forum, W. (2015). New Vision for Education Fostering Social and Emotional Learning through Technology. WEF.

Yalçın, S. (2018). 21. Yüzyıl Becerileri ve Bu Becerilerin Ölçülmesinde Kullanılan Araçlar ve Yaklaşımlar. Ankara Üniversitesi Eğitim Bilimleri Fakültesi Dergisi, 183-201.

Young, J. S. (2012). Linking Learning: Connecting Traditional and Media Literacies in 21st Century Learning. The National Association for Media Literacy Education's Journal of Media Literacy Education 4(1), 70-81. 